\title{
ZASTOSOWANIE KONCEPCJI \\ LEAN MANAGEMENT W SZPITALNYCH ODDZIAŁACH RATUNKOWYCH
}

DOI: $10.33141 /$ po.2019.12.06

\author{
Urszula Cegłowska, Stanisław Brzozowski, \\ Tomasz Hermanowski, Małgorzata Chmielewska
}

\section{Wprowadzenie}

S zpitalny oddział ratunkowy (SOR) jest to jednostka udzielająca świadczeń opieki zdrowotnej polegających na wstępnej diagnostyce oraz podjęciu leczenia w zakresie niezbędnym dla stabilizacji funkcji życiowych osób, które znajdują się w stanie nagłego zagrożenia zdrowotnego (Dz.U. z 2015 r. poz. 178 z późn. zm.). Zgodnie z Rozporządzeniem Ministra Zdrowia $\mathrm{z}$ dnia 3 listopada $2011 \mathrm{r}$. w sprawie szpitalnego oddziału ratunkowego, w skład SOR wchodzą takie obszary, jak: segregacji medycznej i rejestracji, resuscytacyjno-zabiegowy, wstępnej intensywnej terapii, terapii natychmiastowej, obserwacji, konsultacyjny, stacjonowania zespołów ratownictwa medycznego (jeżeli oddział ma w swojej strukturze zespoły ratownictwa medycznego) oraz zaplecza administracyjno-gospodarczego. Obszar segregacji medycznej, rejestracji i przyjęć obejmuje przede wszystkim przeprowadzenie wstępnej oceny pacjenta w stanie nagłego zagrożenia zdrowotnego oraz w razie konieczności transport do innych obszarów oddziału ratunkowego lub innych oddziałów szpitala i/lub rozpoczęcie niezbędnego leczenia.

Oddział ratunkowy jest kluczową komórką organizacyjną w strukturze całego szpitala i nieefektywne zarządzanie nią może mieć wpływ na funkcjonowanie innych oddziałów szpitala (Mazzocato, 2012, s. 1) Często liczba pacjentów zgłaszających się do oddziałów ratunkowych przekracza możliwości SOR w zakresie szybkiej diagnostyki pacjentów i zaordynowania właściwego leczenia. Nadmierne obłożenie oddziałów ratunkowych przekłada się na zwiększony wskaźnik śmiertelności, spadek satysfakcji pacjentów z otrzymanych usług zdrowotnych, spadek satysfakcji personelu medycznego $\mathrm{z}$ wykonywanej pracy oraz nieefektywne zużycie zasobów.

W procesie rejestracji i diagnozowania pacjentów na oddziale ratunkowym udział biorą: lekarz, lekarz rezydent, pielęgniarka, pielęgniarka ze specjalizacją w zakresie medycyny ratunkowej. Przy czym często jedynie 30\% pacjentów trafiających na SOR wymaga konsultacji lekarskich. Większość przypadków może być konsultowana przez odpowiednio przeszkoloną pielęgniarkę oddziału ratunkowego (Davies, 2007, s. 1520). Przedłużający się czas oczekiwania pacjenta na udzielenie świadczenia jest często wynikiem nieprawidłowego dostosowania zasobów, rozumianego jako liczba personelu medycznego oraz dostępnej infrastruktury do liczby pacjentów trafiających do oddziału ratunkowego. Dostosowanie zasobów do liczby pacjentów wymagających leczenia przekłada się na efektywność przepływu pacjentów i efektywność udzielania świadczeń (Setijono, 2010, s. 235). Na SOR notowana jest duża zmienność godzinowa przyjmowanej liczby pacjentów, a niekiedy sezonowa (np. na oddziale ratunkowym w szpitalu pediatrycznym) oraz duża różnorodność dolegliwości, z którymi trafiają pacjenci i szukają opieki medycznej (Mazzocato, 2012, s. 2). Do najczęściej popełnianych błędów w oddziale ratunkowym należą: nieprawidłowo postawiona diagnoza, transport pacjenta do niewłaściwego oddziału oraz zbyt długi czas oczekiwania.

Poprawa funkcjonowania oddziałów ratunkowych, przy uwzględnieniu zwiększania efektywności udzielania świadczeń, radzenia sobie $\mathrm{z}$ nadmiernym obłożeniem oddziału, obniżenia kosztów funkcjonowania oraz zwiększenia bezpieczeństwa pacjentów, stanowi istotny obszar potrzebnych zmian. Kluczowe jest zwrócenie uwagi na brak standaryzacji, fragmentaryczność opieki i brak koordynacji pomiędzy następującymi po sobie etapami $\mathrm{w}$ procesie udzielania świadczeń w oddziale ratunkowym (Mazzocato, 2012, s. 3). Wyróżnia się następujące etapy procesu przejścia pacjenta przez SOR: przyjazd pacjentów do oddziału ratunkowego (we własnym zakresie lub transport ambulansem), wstępna stratyfikacja pacjentów, wykonanie niezbędnych badań diagnostycznych, zdefiniowanie zaleceń terapeutycznych, a następnie wypisanie pacjenta $z$ oddziału ratunkowego lub przyjęcie na inny oddział szpitalny (rys. 1).

\begin{tabular}{|l|l|l|l|l}
1 Przyjazd na SOR & Triage* & 3 Diagnostyka & 4 Terapia & $\begin{array}{c}5 \text { Wypis z SOR/ } \\
\text { przyjęcie do szpitala }\end{array}$ \\
\hline
\end{tabular}

*Triage - system segregacji pacjentów w zależności od stopnia skomplikowania przypadku Rys. 1. Etapy procesu na szpitalnym oddziale ratunkowym (SOR) Źródło: opracowanie własne 
Odpowiedzią na powyższe potrzeby może być wdrożenie zarządzania szpitalnymi oddziałami ratunkowymi w oparciu o koncepcję lean. Lean management, tzw. szczupłe zarządzanie, jest zbiorem metod oraz narzędzi wywodzących się z Systemu Produkcyjnego Toyoty i stosowane $\mathrm{w}$ wielu sektorach przemysłu i usług. Został wdrożony również $\mathrm{w}$ sektorze ochrony zdrowia. Jednym $\mathrm{z}$ pierwszych systemów, który go zastosował, była Narodowa Służba Zdrowia (ang. National Health Service) w Anglii. Wykorzystanie koncepcji lean w organizacji oddziałów ratunkowych jest szczególnie rozpowszechnione w takich państwach, jak Stany Zjednoczone, Australia oraz Kanada (Holden i in., 2011). Począwszy od roku 2000 zastosowanie lean w obszarze ochrony zdrowia stawało się coraz popularniejszym narzędziem poprawy funkcjonowania podmiotów świadczących usługi zdrowotne. Wykorzystanie narzędzi lean w ochronie zdrowia skupia się wokół poprawy jakości i efektywności procesu świadczenia usług zdrowotnych. Punktem wyjścia jest zdefiniowanie korzyści po stronie pacjenta, na przykład poprzez uzyskiwanie poszczególnych świadczeń w optymalnym czasie. Najczęściej osiąganą korzyścią z wdrożenia podejścia lean na oddziałach ratunkowych jest skrócenie czasu oczekiwania bądź długości pobytu (Mazzocato i in., 2014, s. 267).

Tematyka optymalizacji procesu identyfikacji, diagnozowania i ustalania ścieżki terapeutycznej pacjentów znajdujących się w szpitalnym oddziale ratunkowym jest szczególnie istotna $\mathrm{z}$ uwagi na fakt, że czas jest głównym czynnikiem rokowniczym w przypadku wielu stanów nagłych, w tym również bezpośrednio zagrażających życiu. Jednocześnie szpitalne oddziały ratunkowe w ponad $60 \%$ przypadków obciążone są tzw. pacjentami ambulatoryjnymi, których stan zdrowia nie wymaga natychmiastowej interwencji, a porada powinna im być udzielona w podstawowej opiece zdrowotnej, ambulatoryjnej opiece specjalistyczne czy też $\mathrm{w}$ ramach nocnej pomocy lekarskiej (wniosek $\mathrm{z}$ analizy pacjentów w gabinetach Triage, przeprowadzonej w ramach projektu LeanOZ w SOR Wojewódzkiego Wielospecjalistycznego Centrum Onkologii i Traumatologii im. M. Kopernika w Łodzi w lipcu i sierpniu 2017 r.).

Jednym $\mathrm{z}$ podstawowych narzędzi wykorzystywanych $\mathrm{w}$ lean management $\mathrm{w}$ ochronie zdrowia jest mapa strumienia wartości (ang. Value Stream Mapping - VSM), które wiąże się z wizualizacją procesów celem analizy i optymalizacji strumieni wartości. Dzięki VSM istnieje możliwość przedstawienia na jednym schemacie graficznym najważniejszych parametrów i wskaźników opisujących całość procesu leczenia pacjentów i jednocześnie uwidocznienie marnotrawstwa (jap. muda), co pozwala na rozpoczęcie procedur usprawniania procesów w podmiotach leczniczych. Celem niniejszego artykułu jest analiza zastosowania VSM w szpitalnych oddziałach ratunkowych zgodnie z poniżej opisaną metodą ${ }^{1}$.

\section{Metoda badawcza}

W ramach prac nad projektem badawczym lean management $w$ ochronie zdrowia (LeanOZ) finansowanym ze środków Narodowego Centrum Badań i Rozwoju ${ }^{2}$ stworzono bazę wiedzy, tj. elektroniczne zestawienie publikacji o tematyce mapowania strumienia wartości w ochronie zdrowia. Ich identyfikacja nastąpiła poprzez systematyczny przegląd bibliograficznych baz danych Medline, Embase, Scopus oraz ProQuest za pomocą odpowiednio skonstruowanej strategii wyszukiwania zawierającej słowa kluczowe: "lean management”, "health care”, „value stream mapping” oraz ich synonimy. Synonimy poszczególnych słów kluczowych połączono operatorem logicznym „OR”, zaś grupy synonimów operatorem logicznym „AND”. Wyszukiwanie słów kluczowych przeprowadzono w tytułach, abstraktach oraz zastosowano do pełnych tekstów publikacji. Okres wyszukiwania obejmował czas od początku utworzenia wskazanych baz bibliograficznych do dnia 15.11.2015 roku. Następnie 10 analityków, w zespołach dwuosobowych, oceniło każdy z abstraktów pod kątem zasadności włączenia do przeglądu. Abstrakty zakwalifikowane do dalszego etapu podzielono według metodyki badania (przegląd systematyczny, przegląd niesystematyczny, badania oryginalne oraz opisy przypadków), obszaru świata, jakiego badanie dotyczyło (Polska, Europa, kraje poza Europa) oraz oceniono przydatność badań w 5-stopniowej skali ${ }^{3}$. Dodatkowo, każdej z publikacji nadano słowa kluczowe, zdefiniowane na potrzeby projektu LeanOZ, tj.: cost, efficiency, process, quality, hospital, innovation, resource, improvement, standard, time, muda, value stream mapping, patient. Łącznie skategoryzowano 1168 publikacji, których bibliografię umieszczono w pliku Excel. Tak utworzona baza wiedzy pozwala na szybką identyfikację publikacji na potrzeby prac prowadzonych w projekcie LeanOZ.

$\mathrm{Na}$ potrzeby niniejszego opracowania wyselekcjonowano artykuły dotyczące wykorzystania mapowania strumienia wartości $\mathrm{w}$ badaniach mających na celu poprawę funkcjonowania szpitalnych oddziałów ratunkowych. Uwzględniono badania pierwotne dotyczące krajów Europy. Do krytycznego przeglądu piśmiennictwa włączono wszystkie 7 zidentyfikowanych publikacji oceniających wykorzystanie narzędzi lean w szpitalnych oddziałach ratunkowych. W dalszej części artykułu badania zostaną szczegółowo scharakteryzowane.

\section{Wyniki badań}

B adania włączone do przeglądu były realizowane w Wielkiej Brytanii (McCulloch i in., 2010; Davies i in., 2007), Irlandii (Ryan i in., 2013), Szwecji (Mazzocato i in., 2014; Mazzocato i in., 2012; Setijono i in., 2010) i w Niemczech (Hogan i in., 2012). W większości przypadków oddziały ratunkowe umiejscowione były w szpitalach wieloprofilowych, w dwóch badaniach były to szpitale o profilu laryngologicznym (Mazzocato i in., 2012; Mazzocato i in., 2014). We wszystkich badaniach zastosowano mapowanie strumienia wartości. Celem badań opisanych w zidentyfikowanych artykułach była przede wszystkim redukcja czasu od momentu pojawienia się pacjentów w oddziale ratunkowym do wstępnej oceny przeprowadzonej przez lekarza, a także skrócenie całkowitego czasu przebywania $\mathrm{w}$ oddziale, poprawa jakości świadczonych usług poprzez unikanie błędów 
$\mathrm{w}$ postępowaniu $\mathrm{z}$ pacjentem oraz dostosowanie zasobów (personel medyczny, infrastruktura) do liczby i potrzeb pacjentów znajdujących się w oddziale ratunkowym. Charakterystykę badań przedstawiono w tabeli 1 .

Narodowa Służba Zdrowia (ang. National Health Service) w Wielkiej Brytanii ustaliła jako cel, że 98\% pacjentów zgłaszających się do oddziału ratunkowego powinno otrzymać dalsze wytyczne dotyczące procesu terapeutycznego w ciągu 4 godzin od momentu pojawienia się w oddziale. Natomiast w Irlandii cel ten ustalono na 6 godzin (Ryan i in., 2013, s. 1). W ramach przeglądu zidentyfikowano badania brytyjskie oraz irlandzkie analizujące czas od pojawienia się pacjenta w SOR do momentu postawienia diagnozy. W irlandzkim badaniu (Ryan i in., 2013) do elementów ścieżki mających wartość dodaną dla pacjenta zaliczono przeprowadzenie oceny stanu zdrowia przez lekarza oraz późniejszą konsultację wyników badań, wykonanie badań laboratoryjnych oraz badania radiologicznego. Za elementy procesu nieprzynoszące korzyści pacjentowi uznano czasy oczekiwania na wykonanie wymienionych powyżej czynności oraz czas oczekiwania na wynik badań lub przyjęcie do szpitala. Etapy procesu zidentyfikowane jako nieprzynoszące korzyści pacjentowi stanowią jednocześnie wąskie gardła procesu diagnozowania i postępowania z pacjentami trafiającymi do szpitalnych oddziałów ratunkowych. W badaniu celem usprawnień połączono wykorzystanie narzędzi lean $\mathrm{z}$ techniką zarządzania wąskim gardłem (ang. TOC - Theory of Constraints), skupiając się na poprawie tych elementów procesu, które w największym stopniu wiążą się z wydłużeniem czasu przebywania pacjenta na oddziale ratunkowym. W wyniku przeprowadzonych analiz podjęto decyzję o zwiększeniu liczby łóżek oddziału ratunkowego dla tzw. pacjentów ostrych, wprowadzono zintegrowany system zarządzania informacją o pacjentach, poprawiono koordynację prac pomiędzy Pracownią Radiologii i innymi miejscami realizacji świadczeń, poszerzono kompetencje pielęgniarek oddziałów ratunkowych w zakresie możliwości zlecania badań radiologicznych, zwiększono liczbę pielęgnia-

Tabela 1. Badania europejskie oceniające wykorzystujące mapowania strumienia wartości w oddziale ratunkowym

\begin{tabular}{|c|c|c|c|c|}
\hline Badanie & Profil szpitala & Interwencje & $\begin{array}{c}\text { Liczba } \\
\text { obserwowanych } \\
\text { pacjentów }\end{array}$ & Wyniki/ Wnioski \\
\hline $\begin{array}{l}\text { P. Mazzocato } \\
\text { i in., } 2014 \\
\text { Szwecja }\end{array}$ & $\begin{array}{l}7 \text { oddziałów } \\
\text { ratunkowych: } \\
\text { chirurgiczny, } \\
\text { internistyczny, } \\
\text { pediatryczny }(\mathrm{x} 2) \text {, } \\
\text { ginekologiczny, } \\
\text { laryngologiczny }(\mathrm{x} 2) \text {; }\end{array}$ & $\begin{array}{l}\text { Mapowanie } \\
\text { strumienia wartości }\end{array}$ & Brak informacji & $\begin{array}{l}\text { Skuteczność zastosowania narzędzi lean w poprawie } \\
\text { efektywności procesów w szpitalnym oddziale } \\
\text { ratunkowym zależy od stopnia skomplikowania } \\
\text { procesu diagnostyczno-terapeutycznego } \\
\text { Wyznacznikiem sukcesu jest również stosunek } \\
\text { szpitala jako instytucji oraz jej pracowników, do } \\
\text { ciągłego uczenia się i optymalizacji procesów }\end{array}$ \\
\hline $\begin{array}{l}\text { A. Ryan i in., } \\
2013 \\
\text { Irlandia }\end{array}$ & Ogólny & $\begin{array}{l}\text { Mapowanie } \\
\text { strumienia wartości } \\
\text { Teoria ograniczeń } \\
\text { (TOC) }\end{array}$ & 599 & $\begin{array}{l}\text { Prawdopodobieństwo wydłużenia pobytu pacjenta } \\
\text { na oddziale ratunkowym }>4 \text { h było związane } \\
\text { z koniecznością wykonywania następujących } \\
\text { czynności: } \\
\text { - Przyjęcie do szpitala } \\
\text { - Badanie radiologiczne } \\
\text { - Badanie krwi }\end{array}$ \\
\hline $\begin{array}{l}\text { P. Mazzocato } \\
\text { i in., } 2012 \\
\text { Szwecja }\end{array}$ & Pediatria & $\begin{array}{l}\text { Mapowanie } \\
\text { strumienia wartości }\end{array}$ & Brak informacji & Redukcja czasu oczekiwania (19-24\%) \\
\hline $\begin{array}{l}\text { B. Hogan i in., } \\
2012 \\
\text { Niemcy }\end{array}$ & Ogólny & $\begin{array}{l}\text { Mapowanie } \\
\text { strumienia wartości }\end{array}$ & 3230 & $\begin{array}{l}\text { Redukcja czasu do przeprowadzenia wstępnego } \\
\text { badania pacjenta (mediana: } 47,6 \mathrm{~min} \text { vs } 11,2 \mathrm{~min} \text { ) }\end{array}$ \\
\hline $\begin{array}{l}\text { D. Setijono } \\
\text { i in., } 2010 \\
\text { Szwecja }\end{array}$ & Ogólny & $\begin{array}{l}\text { Mapowanie } \\
\text { strumienia wartości }\end{array}$ & 9000 & $\begin{array}{l}\text { Redukcja czasu przeznaczonego na wykonywanie } \\
\text { czynności nieprzynoszących korzyści pacjentowi } \\
\text { Skrócenie całkowitego czasu przebywania pacjenta } \\
\text { w oddziale ratunkowym }\end{array}$ \\
\hline $\begin{array}{l}\text { P. McCulloch } \\
\text { i in., } 2010 \\
\text { Wielka } \\
\text { Brytania }\end{array}$ & Chirurgia & $\begin{array}{l}\text { Mapowanie } \\
\text { strumienia wartości } \\
5 \mathrm{~S}\end{array}$ & 1209 & $\begin{array}{l}\text { Spadek liczby pacjentów kwalifikowanych do } \\
\text { przyjęcia na oddział ( } 27 \% \text { vs } 20 \% \text { ) } \\
\text { Zwiększenie compilance w stosowaniu się personelu } \\
\text { medycznego do wytycznych }\end{array}$ \\
\hline $\begin{array}{l}\text { R. Davies, } \\
2007 \\
\text { Wielka } \\
\text { Brytania }\end{array}$ & Ogólny & $\begin{array}{l}\text { Mapowanie } \\
\text { strumienia wartości }\end{array}$ & Brak informacji & $\begin{array}{l}\text { Efektywniejsze wykorzystania czasu personelu } \\
\text { medycznego } \\
\text { Skrócenie czasu oczekiwania na otrzymanie } \\
\text { świadczenia }\end{array}$ \\
\hline
\end{tabular}

Źródło: opracowanie własne 
rek zatrudnionych na SOR oraz stworzono możliwość wezwania lekarzy dyżurujących na innych oddziałach szpitala, jeżeli zaistnieje taka konieczność (Ryan i in., 2013, s. 106-107).

W brytyjskim badaniu (McCulloch i in., 2010) analizowano oddział ratunkowy o profilu chirurgicznym. Wdrożenie narzędzi lean ukierunkowane było na poprawę bezpieczeństwa pacjentów. Wykonano analizę występowania zdarzeń niepożądanych w kohorcie pacjentów przyjętych przed wdrożeniem rozwiązań lean oraz w kohorcie pacjentów, przyjętych po wdrożeniu narzędzi lean. Do działań zwiększających bezpieczeństwo pacjentów zaliczono m.in. profilaktykę zakrzepicy żył głębokich, ograniczenie błędów w preskrypcji leków, monitoring funkcji życiowych pacjentów oraz higienę rąk personelu medycznego. Pomimo poprawy wskaźnika compliance, w zakresie stosowania się do interwencji ograniczających ryzyko wystąpienia zdarzeń niepożądanych, nie stwierdzono istotnych statystycznie różnic pomiędzy występowaniem zdarzeń niepożądanych przed wdrożeniem interwencji i po jej wdrożeniu. Jednakże, jak zaznaczają autorzy badania, wielkość próby mogła nie pozwolić na wykrycie istotnych statystycznie różnic w występowaniu tych punktów końcowych. Zaobserwowano natomiast zmniejszenie liczby pacjentów hospitalizowanych na innych oddziałach szpitala ( $27 \%$ vs $20 \%$ ), co świadczyło o możliwości uniknięcia niepotrzebnych hospitalizacji (McCulloch i in., 2010, s. 1045-1046). W kolejnym badaniu brytyjskim (Davies, 2007) zastosowano technikę modelowania danych w celu przeanalizowania możliwości skrócenia czasów oczekiwania, ograniczenia czynności nieprzynoszących korzyści oraz poprawy jakości leczenia poprzez ograniczenie liczby błędów medycznych. Analizie podlegały ściśle określone ścieżki pacjentów, uwzględniające kontakt z lekarzem lub pielęgniarką oddziału ratunkowego, wykonanie badania RTG, wdrożenie leczenia lub poradnictwo. Wyniki symulacji wskazują na potrzebę efektywniejszego wykorzystania pracy pielęgniarki oddziału ratunkowego oraz poprawy dostępności lekarza w ciągu trwania poszczególnych dyżurów (Davies, 2007, s. 1520).

W Szwecji dziewięć z dziesięciu funkcjonujących szpitali wdrożyło pewne rozwiązania $z$ zakresu lean. Proces wdrażania narzędzi lean w Szpitalu Uniwersyteckim Karolinska rozpoczęto w 2007 roku, w tym celu wyodrębniono 16 rodzajów świadczeń udzielanych w oddziałach ratunkowych szpitala, które sumarycznie odpowiadały za $60 \%$ wszystkich przyjęć w oddziale. Ostatecznie szczegółowej analizie poddano $9 \mathrm{z}$ wyżej wymienionych świadczeń. Celem projektu było zredukowanie czasu oczekiwania pacjentów od pojawienia się $\mathrm{w}$ oddziale do przeprowadzenia przez lekarza wstępnego badania. Jako target ustawiono 40 minut, zwiększono do $90 \%$ odsetek pacjentów opuszczających oddział w ciągu 4 godzin od pojawienia się w oddziale oraz zmniejszono liczbę pacjentów w oddziale o godzinie $16^{00} \mathrm{w}$ trakcie rozpoczynania się drugiej zmiany. Jako konkluzje $\mathrm{z}$ przeprowadzonych analiz autorzy badania wskazują na konieczność przeanalizowania wzajemnych interakcji pomiędzy poszczególnymi elementami procesu, redukcji elementów procesu nieprzynoszących korzyści pacjentowi oraz poprawę koordynacji pracy poszczególnych jednostek. Dodatkowo, należy mieć na uwadze, że stopień skomplikowania procesu diagnostyczno-terapeutycznego oraz skłonność szpitala do uczenia się, jako organizacji oraz osób w nim zatrudnionych, również będą istotnie wpływały na uzyskany efekt (Mazzocato i in., 2014, s. 282-284).

W kolejnym szwedzkim badaniu (Setijono i in., 2010) przeprowadzono symulacje komputerowe, wykorzystując rzeczywiste dane dotyczące pacjentów przyjętych w oddziale ratunkowym szpitala Sahlgrenska w Göteborgu, celem zaproponowania metod usprawnienia przepływu pacjentów oraz skrócenia czasu oczekiwania. Oszacowano, że całkowity czas przebywania pacjenta w oddziale ratunkowym wynosi 433 minuty, przy czym czas realizacji interwencji przynoszących korzyść pacjentowi wynosi 279 minut. Jako interwencje nieprzynoszące korzyści pacjentom określono czas oczekiwania pacjenta na dokonanie klasyfikacji w systemie triage oraz czas oczekiwania na wykonanie badania podmiotowego przez lekarza. Wyniki przeprowadzonych symulacji wskazały na konieczność zwiększania zatrudnienia $\mathrm{w}$ oddziale ratunkowym o trzy etaty lekarskie, w tym jednego chirurga (Setijono i in., 2010, s. 240-244).

Pierwszym kontaktem pacjentów trafiających na oddział ratunkowy $\mathrm{w}$ badaniu niemieckim (Hogan $\mathrm{i}$ in., 2012) był lekarz w trakcie specjalizacji, co istotnie wydłużało czas pierwszego badania oraz zwiększało liczbę zlecanych badań diagnostycznych. Lekarz ze specjalizacją włączany był na kolejnym etapie jako osoba nadzorująca. Odwrócenie tej kolejności, jako pierwszy badanie przeprowadza lekarz specjalista i określa dalszą ścieżkę leczenia, a lekarz w trakcie specjalizacji kontynuuje wskazaną diagnostykę, a następnie po uzyskaniu wyników ponownie konsultuje się ze specjalistą, pozwoliło skrócić czas oczekiwania do pierwszej oceny pacjenta oraz zredukować liczbę wykonywanych badań diagnostycznych (Hogan i in., 2012, s. 138).

\section{Dyskusja}

W yniki światowych badań dotyczących poprawy jakości świadczeń w lecznictwie zamkniętym koncentrują się na problemach dotyczących zoptymalizowania procesu przepływu pacjentów w szpitalach (Baker i in., 2009, s. 1-168; Bucci i in., 2016, s. 4209). Podkreśla się, że większość nadrzędnych celów szpitala, jak zwiększenie wydajności pracy lekarzy na oddziale ratunkowym, poprawienie dostępu pacjenta do usług zdrowotnych i diagnoza choroby w krótszym czasie, oraz zmniejszenie kosztów, a także zredukowanie czasu pobytu pacjenta i zmniejszenie liczby zakażeń szpitalnych, sprowadza się do problemu długości szpitalnego pobytu pacjenta. Im dłuższy pobyt pacjenta, tym większe generowanie kosztów i możliwość częstszych 
błędów, które dodatkowo prowadzą do wydłużenia czasu hospitalizacji pacjenta (Dammand i in., 2014, s. 19-31).

Zastosowanie mapowania strumienia wartości, jako pojedynczej interwencji lub $\mathrm{w}$ połączeniu $\mathrm{z}$ innymi narzędziami lean, w szpitalnym oddziale ratunkowym, na podstawie opisanych badań, miało na celu wyeliminowanie elementów procesu nieprzynoszących korzyści pacjentowi oraz poprawę jakości świadczeń. Do elementów nieprzynoszących korzyści zalicza się przede wszystkim długi czas oczekiwania do pierwszego kontaktu pacjenta $z$ lekarzem, czas oczekiwania na wyniki badań laboratoryjnych oraz diagnostycznych, jak również zlecanie zbyt dużej liczby badań w sytuacji, gdy nie jest to zasadne. Niemieckie badanie (Hogan i in., 2012) wskazuje na konieczność przeprowadzenia wstępnego badania przez lekarza specjalistę, a nie lekarza w trakcie specjalizacji, z uwagi na dopiero co zdobywane doświadczenie tego drugiego, co ma bezpośrednie przełożenie na wydłużenie czasu do postawienia diagnozy. Oznacza to, że tylko w tych szpitalach, w których na oddziałach ratunkowych zapewniona będzie obecność doświadczonych lekarzy ze specjalizacją, istnieje możliwość uzyskania poprawy przepływu pacjentów, a tym samym oszczędzania zasobów i wysoki poziom jakości leczenia. W literaturze przedmiotu można odnaleźć podobne wyjaśnienia - zwraca się uwagę, że dzięki podziałowi pacjentów na przypadki skomplikowane, którymi zajmują się lekarze, i przypadki standardowe, które mogą być przekazywane pod opiekę również pielęgniarkom, można osiągnąć skrócenie czasu pobytu pacjenta na izbie przyjęć i zwiększenie satysfakcji pacjentów (Dammand i in., 2014, s. 26-31).

Zasady lean mogą być niezbędnym narzędziem poprawy przepływu pacjenta $\mathrm{w}$ odniesieniu do kwestii czasu oczekiwania na wyniki wykonywanych badań w laboratoriach. Rezultaty wykorzystania metody lean w laboratorium obejmują poprawę ich czasu od $25 \%$ do $50 \%$ przy wzroście wydajności pracy od $10 \%$ do $35 \%$ (Coons, 2007, s. 6). Jako determinujący czynnik zwiększenia wydajności pracy laborantów klinicznych wskazuje się projekt architektoniczny pomieszczeń, który skraca długość ścieżki, eliminując liczbę kroków poza optymalnym obszarem pracy. Zauważono, że dzięki redukcji pokonywanego dystansu uzyskano odpowiedni czas na przeprowadzane testy, a dzięki temu następuje wzrost produktywności laborantów oraz notowana jest redukcja popełnianych błędów i poprawa jakości wykonywanych badań (Yerian i in., 2012, s. 278-279).

Zastosowanie narzędzi lean w poprawie efektywności funkcjonowania szpitalnych oddziałów ratunkowych ma różną skuteczność w zależności od stopnia skomplikowania procesu diagnostyczno-terapeutycznego. Nieefektywne funkcjonowanie oddziałów ratunkowych ma bezpośrednie przełożenie na wyższy współczynnik śmiertelności pacjentów trafiających do oddziału, spadek satysfakcji personelu medycznego $\mathrm{z}$ wykonywanej pracy, spadek satysfakcji pacjentów $\mathrm{z}$ otrzymywanych świadczeń opieki zdrowotnej oraz nieefektywne zużycie ograniczonych zasobów (Mazzocato i in., 2012, s. 1). Dlatego też podkreśla się szczególnie istotną kwestię prawidłowej koordynacji działań podejmowanych $\mathrm{w}$ różnych miejscach realizacji świadczeń oraz multidyscyplinarnego zespołu medycznego pracującego w oddziale ratunkowym. Poszczególne badania podkreślają rolę pielęgniarki oddziału ratunkowego (Davies, 2007, s. 1521; Ryan i in., 2013, s. 106) oraz zwracają uwagę na potrzebę dostosowania poziomu zatrudnienia personelu medycznego do popytu na usługi świadczone w oddziale ratunkowym (Setijono i in., 2010, s. 245). Zwrócono również uwagę na potrzebę włączenia menedżerów wyższego szczebla w działania ukierunkowane na poprawę procesów realizowanych $\mathrm{w}$ SOR, $\mathrm{z}$ uwagi na konieczność koordynacji działań wielu jednostek szpitala (McCulloch i in., 2010, s. 1046). Warto przy tym zaznaczyć, ze głównym problemem we wspieraniu jakości opieki nad pacjentem, a zarazem największą wadą organizacji szpitala jest brak współpracy między zarządem a personelem medycznym (Leape, 2001, s. 145-148). Literatura sygnalizuje istotność zagadnienia ze względu na istnienie różnic $\mathrm{w}$ celach, priorytetach i wartościach pomiędzy tymi grupami, a te z kolei wynikają $\mathrm{z}$ tradycyjnej przeszkody - podziału opieki na „silosy” czy też piony, oddziały, działy, które tworzą barierę w relacjach (Marren, 2003, s. 208-214). Ocena interakcji międzyludzkich może pokazać, jaki wpływ na skuteczność placówki mają jej członkowie, ich rozwój, klimat pracy, osiągnięcia (Minvielle i in., 2008, s. 8-16). Wydaje się zatem niezbędnym do osiągnięcia sukcesu przy implementacji narzędzi lean w obszarze oddziałów ratunkowych w celu optymalizacji procesu diagnostyczno-terapeutycznego, zapewnienia wsparcia ze strony zarządu szpitala, ordynatorów oddziałów oraz długoterminowego zaangażowania i współpracy wszystkich uczestników procesu wdrażania rozwiązań (McCulloch i in., 2010, s. 1045).

\section{Podsumowanie}

Wyniki zidentyfikowanych badań wskazują na korzyści będące efektem wykorzystania narzędzi lean management, przede wszystkim związane z optymalizacją procesów oraz struktur organizacyjnych szpitala, a także zwiększeniem zaangażowania personelu zatrudnionego w szpitalu. Potencjalne zagrożenia, jak chociażby wzrost kosztów działalności szpitala wynikający z konieczności zatrudnienia dodatkowego personelu lub zwiększenia innych kosztów działalności w fazie implementacji metody lean nie były analizowane. $\mathrm{W}$ ramach przeprowadzonego przeglądu literatury nie zidentyfikowano publikacji dotyczących zastosowania metody VSM w warunkach polskich. Niewątpliwie przeprowadzenie badań empirycznych z wykorzystaniem metody VSM w Polsce byłoby olbrzymią wartością dodaną, zwłaszcza biorąc pod uwagę potencjalne korzyści wskazywane w wynikach europejskich badań oraz toczącą się od dłuższego czasu dyskusję nad koniecznością poprawy efektywności szpitalnych oddziałów ratunkowych w Polsce. 
mgr Urszula Cegłowska

Warszawski Uniwersytet Medyczny

Wydziat Farmaceutyczny

ORCID: 0000-0002-1300-7370

e-mail: uceglowska@gmail.com

\section{mgr Stanisław Brzozowski \\ Polskie Towarzystwo Ekonomiki Zdrowia, \\ Sekcja Lean Management \\ ORCID: 0000-0002-3745-938X \\ e-mail: sbrz@wp.pl}

\section{prof. dr hab. Tomasz Hermanowski \\ Warszawski Uniwersytet Medyczny \\ Wydziat Farmaceutyczny \\ ORCID: 0000-0002-1659-8719}

e-mail: tomasz.hermanowski@wum.edu.pl

\section{dr inż. Małgorzata Chmielewska \\ Warszawski Uniwersytet Medyczny \\ Wydział Farmaceutyczny \\ ORCID: 0000-0002-6566-0902}

e-mail: malgorzata.chmielewska@wum.edu.pl

\section{Przypisy}

1) Artykuł powstał $\mathrm{w}$ wyniku badań przeprowadzonych $\mathrm{w}$ ramach Projektu Lean Management w Ochronie Zdrowia (LeanOZ) finansowanego $\mathrm{w}$ ramach grantu Narodowego Centrum Badań i Rozwoju (grant nr IS-2/200/NCBR/2015).

2) Projekt „LeanOZ”, grant no. /IS-2/200/NCBR/2015, kierownik: prof. dr hab. Tomasz Hermanowski.

3) 1 - zdecydowanie nieprzydatne; 2 - raczej nieprzydatne; 3 - ocena neutralna; 4 - raczej przydatne; 5 - zdecydowanie przydatne.

\section{Bibliografia}

[1] Baker M., Taylor I., Mitchell A. (2009), Making Hospitals Work, Lean Enterprise Academy, Goodrich, UK.

[2] Bucci S., de Belvis A.G., Marventano S., De Leva A.C., Tanzariello M., Specchia M.L., Ricciardi W., Franceschi F. (2016), Emergency Department Crowding and Hospital Bed Shortage: Is Lean a Smart Answer? „European Review for Medical and Pharmcological Sciences", Vol. 20, No. 20, pp. 4209-4219.

[3] Coons J.A. (2007), Beginning the Lean Improvement Journey in the Clinical Laboratory, White Paper [online], https://www. yumpu.com/en/document/read/30068777/beginning-the-lean-improvement-journey-in-the-clinical-laboratory, access date: 25.06 .2018 .

[4] Dammand J., Hørlyck M., Jacobsen T.L., Lueg R., Röck R.L. (2014), Lean Management in Hospitals: Evidence from Denmark, „Administration \& Public Management Review”, No. 23, pp. 19-35.
[5] Davies R. (2007), „See and Treat” or „See” AND „Treat” in an Emergency Department, [in:] S.G. Henderson, B. Biller, M.-H. Hsieh, J. Shortle, J.D. Tew, R.R. Barton (eds.), Proceedings of the 2007 Winter Simulation Conference, IEEE Press, Washington D.C., pp. 1519-1522.

[6] Hogan B., Rasche Ch., Braun von Reinersdorff A. (2012), The First View Concept: Introduction of Industrial Flow Techniques into Emergency Medicine Organization, „European Journal of Emergency Medicine", Vol. 19, No. 3, pp. 136-139.

[7] Holden R.J. (2011), Lean Thinking in Emergency Departments: A Critical Review, „Annals of Emergency Medicine", Vol. 57, No. 3, pp. 265-278.

[8] Leape L.L. (2001), Foreword: Preventing Medical Accidents: Is "Systems Analysis” the Answer? "American Journal of Law \& Medicine", Vol. 27, No. 2-3, pp. 145-148.

[9] Marren J.P. (2003), The Hospital Board at Risk and the Need to Restructure the Relationship with the Medical Staff: Bylaws, Peer Review and Related Solutions, "Annals of Health Law", Vol. 12, No. 2, pp. 179-234.

[10] Mazzocato P., Holden R.J., Brommels M., Aronsson H., Backman U., Elg M., Thor J. (2012), How Does Lean Work in Emergency Care? A Case Study of a Lean-inspired Intervention at the Astrid Lindgren Children's Hospital, Stockholm, Sweden, „BMC Health Services Research”, Vol. 12, No. 28, pp. 1-13.

[11] Mazzocato P., Thor J., Bäckman U., Brommels M., Carlsson J., Jonsson F., Hagmar M., Savage C. (2014), Complexity Complicates Lean: Lessons from Seven Emergency Services, "Journal of Health Organization and Management", Vol. 28, No. 2, pp. 266-288.

[12] McCulloch P., Kreckler S., New S., Sheena Y., Handa A., Catchpole K. (2010), Effect of a "Lean” Intervention to Improve Safety Processes and Outcomes on a Surgical Emergency Unit, „British Medical Journal”, Vol. 341, No. 2, pp. 1043-1047.

[13] Minvielle E., Sicotte C., Champagne F., Contandriopoulos A.P., Jeantet M., Preaubert N., Bourdil A., Richard C. (2008), Hospital Performance: Competing or Shared Values? „Health Policy”, Vol. 87, No. 1, pp. 8-19.

[14] Obwieszczenie Ministra Zdrowia z dnia 12 stycznia 2015 r. w sprawie ogłoszenia jednolitego tekstu Rozporządzenia Ministra Zdrowia w sprawie szpitalnego oddziału ratunkowego, Dz.U. z 2015 r. poz. 178 z późn. zm.

[15] Ryan A., Hunter K., Cunningham K., Williams J., O’Shea H., Rooney P., Hickey F. (2013), STEPS: Lean Thinking, Theory of Constraints and Identifying Bottlenecks in an Emergency Department, „Irish Medical Journal”, Vol. 106, No. 4, pp. 105-107.

[16] Setijono D., Naraghi A.M., Ravipati U.P. (2010), Decision Support System and the Adoption of Lean in a Swedish Emergency Ward: Balancing Supply and Demand towards Improved Value Stream, „International Journal of Lean Six Sigma", Vol. 3, No. 6, pp. 234-248.

[17] Yerian L.M., Seestadt J.A., Gomez E.R., Marchant K.K., (2012), A Collaborative Approach to Lean Laboratory Workstation Design Reduces Wasted Technologist Travel, "American Journal of Clinical Pathology", Vol. 138, pp. 273-280. 


\section{Applying Lean Management Concept in Hospital Emergency Departments}

\section{Summary}

Hospital emergency department (ED) is an important unit in the hospital structure and its inefficient management can affect the functioning of an entire hospital. Considering that time is the major prognostic factor for many life threating situations, optimisation of ED functioning by improving the effectiveness and reducing operating costs, is particularly important. Lean management is a set of methods and tools derived from the Toyota Production System and used in many industry sectors. Lean solutions have been implemented in the healthcare sector in the United States, Australia and Canada. The aim of the paper was to assess the application of lean management in ED in Europe. The literature review was conducted in
Medline, Embase, Scopus and ProQuest databases using "lean management", "health care" and "value stream mapping" as keywords, we searched articles published until $15 / 11 / 2015$. The results showed that the inefficient functioning of EDs has an impact on a higher mortality rate, decrease in the work satisfaction of medical staff, decrease in patient satisfaction with healthcare services received and inefficient use of resources. Proper coordination of services and multidisciplinary role of the medical team are particularly important issues. Implementing lean in the area of EDs requires considering the complexity of the diagnostic or therapeutic process and hospital willingness to learn.

\section{Keywords}

lean management, value stream mapping, emergency department, quality improvement 